\title{
Infection Control Measures in Pakistani Dental Practices During COVID-19 Outbreak
}

\author{
Yashfika Abdul Bari ${ }^{1}$ \\ BDS \\ Syeda Maliha Waqar ${ }^{2}$ \\ BDS \\ Saqif Nasir \\ BDS \\ Kamil Zafar ${ }^{4}$ \\ BDS, FCPS \\ Nabeel Naeem Baig ${ }^{5}$ \\ BDS, MPH \\ Farhana Nazir Shoro ${ }^{6}$ \\ BDS \\ Khadijah Abid ${ }^{7}$ \\ BS Hons, MSc, MSPH
}

OBJECTIVE: The objective of this study is to assess infection control measures in dental practices during COVID-19 outbreak in Pakistan.

METHODOLOGY: It was a cross-sectional web based survey conducted during COVID-19 outbreak from the period of June 2020 to August 2020. The study participants were the dental surgeons who were either working in hospital setup or running their own private practice or working in private dental setup. The survey consisted of sets of questions to assess whether dental practitioners have implemented strategies to combat novel corona virus infection in their practice. It also consists of questions that assess aerosol generating procedures are commencing with or without out any COVID-19 symptoms.

RESULTS: About $39.1 \%$ participants reported that $75 \%$ of the number of patients in their clinic had been reduced and $52.2 \%$ of the participants reported that $>50 \%$ of the patients came for endodontic procedures with pain. Eighty one percent of the participants were maintaining hand hygiene before touching all patients, $71.7 \%$ before any cleaning, $78.3 \%$ before any aseptic procedure, $81 \%$ after exposure to patient's fluid and $80.4 \%$ after touching. There was low compliance regarding the use of personal protective equipment and almost $62.6 \%$ were using eye wear for all patients, $58.7 \%$ were disinfecting whole clinical room before new patient and $43.9 \%$ were using single use (disposable) examination set during COVID-19 outbreak. CONCLUSION: Majority of dentist in Pakistan were following the recommendations and guidelines of infection control practices related to COVID-19 pandemic.

KEYWORDS: COVID-19, coronavirus, infection control measures, practices, dentistry

HOW TO CITE: Bari YA, Waqar SM, Nasir S, Zafar K, Baig NN, Shoro FN, Abid K. Infection control measures in Pakistani dental practices during COVID-19 outbreak. J Pak Dent Assoc 2021;30(3):152-156.

DOI: https://doi.org/10.25301/JPDA.303.152

Received: 04 November 2020, Accepted: 08 April 2021

\section{INTRODUCTION}

$\mathrm{T}$ he recent outbreak of COVID-19 has created havoc and chaos all over the world. It started from a small city of China known as Wuhan in December 2019

1. Student, MJDF RCS Eng (in process), MSc Oral Sciences (in process), Department of Oral Sciences, University of Glasgow.

2. Student, Mphil Trainee, Department of Oral Sciences, Ziauddin University, Karachi.

3. Lecturer, Department of Oral Medicine and Diagnosis, Dow University of Health Sciences, Karachi.

4. Instructor, FCPS, Department of Operative Dentistry, Aga Khan University Hospital, Karachi.

5. Sr Research Executive Officer, Department of Research Evaluation Unit, College of Physicians and Surgeons Pakistan.

6. Student, MSc (in process), Department of Dental Science for Clinical Sciences, Queen Mary University of London.

7. Senior Statistician, MSPH, Department of Research Evaluation Unit, College of Physicians and Surgeons Pakistan.

Corresponding author: "Miss. Khadijah Abid" < khadijahabid@gmail.com > and seized the entire universe gradually. ${ }^{1}$ The dental setup has affected severely since the outbreak of this disease and the dental practitioners are considered amongst the highest risk due to the procedures which generate aerosols especially while using drills and ultrasonic devices which are responsible for aerosol production. ${ }^{2}$ Patients infected with COVID-19 will not only affect the dental practitioner but the surrounding and environment will also be contaminated during the dental procedures therefore many non-urgent and elective procedures has to be suspended or postponed and only emergency cases have to be catered. ${ }^{3}$ In order to minimize the risk, many guidelines and recommendations have been made while dealing the patients in this pandemic to ensure the safety of dentist as well as patient. the use of personal protective equipment which includes facemasks, gloves, gowns and 
Bari YA/ Waqar SM/ Nasir S/ Zafar K/ Baig NN/ Shoro FN/ Abid K/
Infection control measures in Pakistani dental practices during COVID-19 outbreak protective eyewear, rinsing patient's mouth before performing any dental procedure and disinfecting dental units by chemical or non-chemical means have been emphasized to stop the spread of infection. ${ }^{4}$

With all the guidelines, it should be of prime importance to gauge the number of dentist practicing the guidelines made post COVID-19 outbreak. Hence, no studies has been conducted in Pakistan to assess the practice of dental practitioners regarding guidelines of COVID-19 infection, therefore the aim of current study was to assess the infection control measures in dental practices during COVID outbreak in Pakistan. The study would aid in assessing infection control practices that dentists were following and assist us in designing and devising strategies to combat COVID-19 among dental practices.

\section{METHODOLOGY}

It was a cross-sectional web based survey conducted during COVID-19 outbreak from the period of June 2020 to August 2020. The study participants were the dental surgeons who were either working in hospital setup or running their own private practice or working in private dental setup in Pakistan. The proforma was transferred into Google Forms to be accessible to number of dental surgeons via Facebook, WhatsApp and emails. The non-probability convenience sampling technique is used to recruits the study subjects. The age of dental practitioners was 20-50 years and both genders were included.

Ethical approval of the study was taken from ethical review board of Ameen medical and dental center (ERC-AMDC/025/2020). Informed consent was taken from all the study participants digitally through the google forms. The survey form was devised using international guidelines that should be opt in dental practices post COVID-19. Ge Z-y et al. stated all the major changes that should be implemented in dental practices post COVID-19 outbreak to mitigate the contamination and transmission of infection. ${ }^{5}$ The survey form was also devised according to the guidelines set by Bouguezzi A et al. regarding measures taken before each dental treatment. ${ }^{6}$ The survey consist of sets of questions to assess whether dental practitioners have implemented strategies to combat novel Corona virus infection in their practice. It also consists of questions that assess aerosol generating procedures are commencing with or without out any COVID-19 symptoms.

Before analysis responses were checked for duplication and missing values by principal investigator. All the duplicate responses and missing data were excluded from the analysis. Data was analyzed using SPSS version 23. Descriptive analysis of all variables were performed. Results were presented as frequencies and percentages in tabular forms.

\section{RESULTS}

Almost 250 participants were approached out of which 230 responded back and filled the survey. Most of the participants were practicing as dental practitioners from $2-5$ years $(63 \%)$ and the least from $10-15$ years $(5.2 \%)$. The results regarding the setting of dentists practicing, dentist shutting down their clinics, patient outflow in dental clinics, COVID-19 patient's management and patients awareness about the infection control practices specific to COVID-19 are summarized in table 1.

Table 1: Practice of dental practitioners during COVID-19

\begin{tabular}{|c|c|c|}
\hline & $\mathbf{n}$ & $\%$ \\
\hline \multicolumn{3}{|l|}{$\begin{array}{l}\text { How have you changed your practicing hours after } \\
\text { COVID-19 outbreak? }\end{array}$} \\
\hline Complete shutdown until the pandemic is over & 50 & 21.7 \\
\hline For few days as per government orders & 56 & 24.3 \\
\hline Reduce the operating hours & 49 & 21.3 \\
\hline Appointment for emergency cases only & 63 & 27.4 \\
\hline Same as usual days & 12 & 5.2 \\
\hline \multicolumn{3}{|l|}{$\begin{array}{l}\text { By what percentage the no of patients in your clinic } \\
\text { have been decreased? }\end{array}$} \\
\hline $25 \%$ & 42 & 18.3 \\
\hline $50 \%$ & 82 & 35.7 \\
\hline $75 \%$ & 90 & 39.1 \\
\hline $100 \%$ & 16 & 7.0 \\
\hline \multicolumn{3}{|l|}{$\begin{array}{l}\text { How do you deal with the patient suspecting } \\
\text { COVID-19? }\end{array}$} \\
\hline $\begin{array}{l}\text { Reschedule treatment and send the patient for } \\
\text { confirmatory test results of COVID-19 }\end{array}$ & 153 & 66.5 \\
\hline $\begin{array}{l}\text { Continue treatment and advice patient for } \\
\text { confirmatory test results of COVID-19 }\end{array}$ & 4 & 1.7 \\
\hline $\begin{array}{l}\text { Perform emergency treatment and send the patient } \\
\text { for confirmatory test results of COVID-19 }\end{array}$ & 73 & 31.7 \\
\hline \multicolumn{3}{|l|}{$\begin{array}{l}\text { With regard to patient awareness, What percentage } \\
\text { of patients want to know about measures for infection } \\
\text { control measures before treatment post COVID-19 } \\
\text { outbreak as a part of their safety? }\end{array}$} \\
\hline $\mathbf{0 - 2 5 \%}$ & 120 & 52.2 \\
\hline $26-50 \%$ & 55 & 23.9 \\
\hline $51-75 \%$ & 40 & 17.4 \\
\hline $76-100 \%$ & 15 & 6.5 \\
\hline \multicolumn{3}{|l|}{$\begin{array}{l}\text { How have you treated COVID-19 positive patients in } \\
\text { your practice? }\end{array}$} \\
\hline $\begin{array}{l}\text { Perform emergency dental treatment with use of } \\
\text { highest level of PPEs and adequate ventilation in the } \\
\text { room }\end{array}$ & 25 & 10.9 \\
\hline Perform emergency dental treatment only & 13 & 5.7 \\
\hline $\begin{array}{l}\text { Perform emergency dental treatment with use of } \\
\text { highest level of PPEs only }\end{array}$ & 16 & 7.0 \\
\hline No COVID-19 patient till date & 176 & 76.5 \\
\hline
\end{tabular}




\section{Bari YA/ Waqar SM/ Nasir S/} Zafar K/ Baig NN/ Shoro FN/ Abid K/

About $52.2 \%$ of the participants reported that $>50 \%$ of the patients came for endodontic procedures with pain whereas $20.4 \%$ of the participants reported that $>50 \%$ of the patients came for restorative procedures without pain post COVID-19 outbreak. There was a high compliance regarding the participants taking medical and travel history thoroughly every time i.e., 73\%. However, low compliance was reported in checking vitals by the participants. The responses related to the practice of whether the participants had removed the reading material and toys (non-essential objects) from waiting area, changed seating distance of 2 meter, to schedule the patient apart enough to avoid their presence at same time and adequate ventilation of $60 \mathrm{~L} / \mathrm{s}$ per room in their waiting areas is mentioned in table 2. Hygiene and practices for infection control during COVID-19 are

Table 2: During COVID-19 different procedure percentage, precautions and guidelines

\begin{tabular}{|c|c|c|c|}
\hline $\begin{array}{c}\text { What percentage of patients are reporting in your clinic } \\
\text { for the following procedures post COVID-19 outbreak? }\end{array}$ & $<25 \%$ & 25 to $50 \%$ & $>50 \%$ \\
\hline Orthodontic procedures & $194(84.3)$ & $25(10.9)$ & $11(4.8)$ \\
\hline Endodontic procedures with pain & $51(22.2)$ & $59(25.7)$ & $120(52.2)$ \\
\hline Restorative procedures without pain & $117(50.9)$ & $66(28.7)$ & $47(20.4)$ \\
\hline Prosthetics for missing tooth structure & $131(57)$ & $87(37.8)$ & $12(5.2)$ \\
\hline Cosmetic needs such as whitening and veneer & $217(94.3)$ & $13(5.7)$ & - \\
\hline Hygiene needs such as scaling, polishing & $134(58.3)$ & $71(30.9)$ & $25(10.9)$ \\
\hline $\begin{array}{c}\text { With regards to patients, do you practice following } \\
\text { precautions? }\end{array}$ & Every time & $\begin{array}{c}\text { Only in } \\
\text { COVID } \\
\text { suspected } \\
\text { patients }\end{array}$ & Often \\
\hline Do you take thorough medical and travel history? & $168(73)$ & $19(8.3)$ & $43(18.7)$ \\
\hline Do you run a temperature check? & $114(49.6)$ & $73(31.7)$ & $43(18.7)$ \\
\hline $\begin{array}{c}\text { Do you assess respiratory tract symptoms like persistent } \\
\text { cough, shortness of breath and loss of smell closely? }\end{array}$ & $\begin{array}{c}114 \\
(49.6 \%)\end{array}$ & $75(32.6)$ & $41(17.8)$ \\
\hline $\begin{array}{c}\text { Have you changed the waiting area of your clinic by } \\
\text { implementing following guidelines? }\end{array}$ & Yes & In process & $\begin{array}{c}\text { Not } \\
\text { intended }\end{array}$ \\
\hline $\begin{array}{c}\text { Remove the reading material and toys (non-essential } \\
\text { objects) from waiting area }\end{array}$ & $139(60.4)$ & $37(16.1)$ & $54(23.5)$ \\
\hline $\begin{array}{c}\text { Seating distance of 2m in your waiting area as per the } \\
\text { guidelines }\end{array}$ & $175(76.1)$ & $41(17.8)$ & $14(6.1)$ \\
\hline $\begin{array}{c}\text { Practice scheduling the patient apart enough to avoid } \\
\text { their presence at same time }\end{array}$ & $179(77.8)$ & $39(17)$ & $12(5.2)$ \\
\hline $\begin{array}{c}\text { Adequate ventilation of 60L/s is available } \\
\text { forl }\end{array}$ & $126(54.8)$ & $59(25.6$ & $45(19.6)$ \\
\hline
\end{tabular}

Table 3: Hygiene related practices for infection control during COVID-19

\begin{tabular}{|c|c|c|c|c|}
\hline When do you maintain hand hygiene? & Not at all & $\begin{array}{c}\text { Only in } \\
\text { COVID-19 } \\
\text { confirmed } \\
\text { Patients }\end{array}$ & $\begin{array}{c}\text { Only in } \\
\text { suspected } \\
\text { Patients }\end{array}$ & $\begin{array}{c}\text { In all } \\
\text { patients }\end{array}$ \\
\hline Before touching patient & $23(10)$ & $\begin{array}{c}\text { Does this } \\
\text { mean none } \\
\text { practice } \\
\text { hand } \\
\text { hygiene?- }\end{array}$ & $21(9.1)$ & $186(80.9)$ \\
\hline Before any cleaning & $42(18.3)$ & $2(0.9)$ & $21(9.1)$ & $165(71.7)$ \\
\hline Before any aseptic procedure & $33(14.3)$ & $2(0.9)$ & $15(6.5)$ & $180(78.3)$ \\
\hline After exposure to patient's fluid & $31(13.5)$ & $? ?$ & $12(5.2)$ & $187(81.3)$ \\
\hline After touching patient & $20(8.7)$ & $11(4.8)$ & $14(6.1)$ & $185(80.4)$ \\
\hline After touching patient's surrounding & $21(9.1)$ & $12(5.2)$ & $16(7)$ & $181(78.7)$ \\
\hline $\begin{array}{l}\text { With regards to Infection control, what } \\
\text { do you follow before any dental } \\
\text { procedure }\end{array}$ & $? ?$ & $? ?$ & $? ?$ & $? ?$ \\
\hline Use of eye-wear & $30(13)$ & $17(7.4)$ & 39 (17) & $144(62.6)$ \\
\hline Use of Face shields & $32(13.9)$ & $24(10.4)$ & $47(20.4)$ & $127(55.2)$ \\
\hline Use of face masks & $18(7.8)$ & $-? ? ?$ & 27 (11.7) & $185(80.4)$ \\
\hline Use of respirator & $105(45.7)$ & $20(8.7)$ & $54(23.5)$ & $51(22.2)$ \\
\hline Use of high volume evacuator & $91(39.6)$ & $15(3.6)$ & $38(16.5)$ & $86(37.4)$ \\
\hline
\end{tabular}

Infection control measures in Pakistani dental practices during COVID-19 outbreak

\begin{tabular}{|c|c|c|c|c|}
\hline Use of high efficiency particulate arrestor & $129(56.1)$ & $10(4.3)$ & $44(19.1)$ & $47(20.4)$ \\
\hline $\begin{array}{c}\text { Disinfecting whole clinical room before } \\
\text { new patient }\end{array}$ & $52(22.6)$ & $7(3)$ & $36(15.7)$ & $135(58.7)$ \\
\hline $\begin{array}{c}\text { Use of single use (disposable) } \\
\text { examination set }\end{array}$ & $77(33.5)$ & $7(3)$ & $45(19.6)$ & $101(43.9)$ \\
\hline $\begin{array}{c}\text { With regards to treatment, what practice } \\
\text { do you follow during COVID-19? }\end{array}$ & & & & \\
\hline $\begin{array}{c}\text { Rinsing patient's mouth with } \\
\text { chlorhexidine before commencing any } \\
\text { treatment }\end{array}$ & $86(37.4)$ & $18(7.8)$ & $35(15.2)$ & $91(39.6)$ \\
\hline $\begin{array}{c}\text { Using rubber dam in all aerosol } \\
\text { generating procedures }\end{array}$ & $76(33)$ & $24(10.4)$ & $27(11.7)$ & $103(44.8)$ \\
\hline $\begin{array}{c}\text { Using Hand instrumentation for } \\
\text { periodontal procedures }\end{array}$ & $114(49.6)$ & $11(4.8)$ & $33(14.3)$ & $72(31.3)$ \\
\hline $\begin{array}{c}\text { Replacing the high speed hand piece with } \\
\text { the low speed or be less invasive }\end{array}$ & $75(32.6)$ & $23(10)$ & $34(14.8)$ & $98(42.6)$ \\
\hline $\begin{array}{c}\text { Using salivary suction for prosthodontic } \\
\text { procedures }\end{array}$ & $56(24.3)$ & $16(7)$ & $18(7.8)$ & $140(60.9)$ \\
\hline $\begin{array}{c}\text { Applying oral mucosa anesthesia to the } \\
\text { throat before impression taking }\end{array}$ & $119(51.7)$ & $22(9.6)$ & $30(13)$ & $59(25.7)$ \\
\hline
\end{tabular}

summarized in table 3. Participants were shown to follow hand hygiene practices almost $70-81 \%$. There was low compliance of using other personal protective equipment's i.e., eye wear, and gowns. The details of other hygiene and infection control practices during COVID-19 is listed in table 3.

\section{DISCUSSION}

The COVID-19 is an exceptional condition that has affected the health care workers globally especially dental health care providers. This cross-sectional study evaluates the compliance and practices of the infection control measures taken by Pakistani dentist.

The COVID-19 pandemic have resulted in significant change in the practices of dentist affecting the working hours and thus substantial reduction in number of patients. The present study reported almost $95 \%$ of drop in the working hours due to complete shutdown or just few hours of working at alternate days as per local government policies.

According to the American Dental Association, all elective dental care procedures such as fillings, scaling and polishing, orthodontic, cosmetic dentistry and prosthodontic work should be postponed during the pandemic. This has resulted in only dealing with dental emergencies including symptomatic irreversible pulpitis, acute apical abscesses, avulsion or luxation injuries and cellulitis. The finding of this study are in accordance with these guideline and the most commonly performed procedure was endodontics with more than $50 \%$ of patients presented to the clinics with severe pain. ${ }^{7}$

With regards to the question of taking history and pre-operative assessment before treating the patients, most of the practitioners responded that they perform thorough assessment only in COVID-19 suspected individuals. In contrary to this, studies in Jordanian, Norwegian and Italian dentists have reported lack of effective pre-operative 
Bari YA/ Waqar SM/ Nasir S/ Zafar K/ Baig NN/ Shoro FN/ Abid K/

assessment of patients related to COVID-19 signs and symptoms. ${ }^{8-10}$

Question was also asked about the precautions taken at the waiting area. In this study, $76.1 \%$ of dentist were following seating distance protocol in their clinical setting areas. The result of our study is in line with the Cagetti et al. study who also reported $74 \%$ of dentist following the seating distance protocol. ${ }^{8}$ This needs to be improved until the pandemic completely ends. WHO recommends the use of negative pressure rooms with a minimum of 12 air changes per hour or at least $160 \mathrm{~L} / \mathrm{s}$ per patient for the treatment of confirmed or suspected cases of COVID-19. Only 54\% of dentist in the present study were having adequately ventilated rooms. These findings are in contrary to the study in Italian dentist who were having $88 \%$ ventilated rooms. ${ }^{8}$

Before starting any treatment in COVID-19 suspected or confirmed patient certain measures such as pre-operative mouth rinse, rubber dam application, high suction evacuator etc. are followed to prevent contamination of operatory with the aerosol generating procedures (AGP). ${ }^{11}$ Only $23 \%$ of Pakistani dentist were using Chlorhexidine as a pre-operative mouth rinsing protocol in COVID-19 suspected or confirmed cases. However, 54\% Italian dentist were turned out to using the same protocol. ${ }^{8}$

The practice of using personal protective equipment such as N-95 mask. Eye wear, gloves, gowns and face shields has been recommended to prevent cross infection. In this study, $62 \%$ of dentist were wearing goggles, where as $55.2 \%$, $80.4 \%$ and $22.2 \%$ were using face shields, face masks, and respirators, respectively. The findings of Khader et al. assesses awareness only and Modi et al. were found out to be similar to our study. ${ }^{9,12}$ However, Gambhir et al. reported the lack of awareness of one third of dentist about the proper PPE in Indian dentists. ${ }^{13}$ Studies have also been conducted comparing the masks and respirators in controlling the infection in similar pandemics previously which showed thirty times greater superiority of N95 or respirators over masks. ${ }^{14-16}$ Respirators offer considerably better resistance to fluid penetration forming the seal around the mouth and nose. The lower numbers of respirator use by dentist can have serious consequences. Hence it is recommended to use respirators during this COVID-19 pandemic. ${ }^{17}$

The strengths of the study are its good response rate, practice and attitudes of dentists towards infection control measures were assessed. This study will also help in improving and setting up guidelines further regarding the infection control practices. The limitations are small size and thus lack of generalizability of results to Pakistani dentists. Another limitation of our survey is response bias. Similar studies were also conducted in different parts of the world with variable questionnaire. So there is also a need to
Infection control measures in Pakistani dental practices during COVID-19 outbreak

formulate a uniform questionnaire form for assessing the infection control practices particularly for pandemics.

\section{CONCLUSION}

Majority of dentist in Pakistan were following the recommendations and guidelines of infection control practices related to COVID-19 pandemic. However, there are still few areas such as waiting area settings, use of respirators and other PPEs which needs improvement.

\section{CONFLICT OF INTEREST}

None to declare

\section{REFERENCES}

1. Abid K, Bari YA, Younas M, Tahir Javaid S, Imran A. Progress of COVID-19 epidemic in Pakistan. Asia Pac J Public Health. 2020;32: 154-56.

https://doi.org/10.1177/1010539520927259

2. To KK-W, Tsang OT-Y, Yip CC-Y, Chan K-H, Wu T-C, Chan JMC, et al. Consistent detection of 2019 novel coronavirus in saliva. Clin Infect Dis. 2020;71:841-43.

https://doi.org/10.1093/cid/ciaal49

3. Liu L, Wei Q, Alvarez X, Wang H, Du Y, Zhu H, et al. Epithelial cells lining salivary gland ducts are early target cells of severe acute respiratory syndrome coronavirus infection in the upper respiratory tracts of rhesus macaques J Virol. 2011;85:4025-030.

https://doi.org/10.1128/JVI.02292-10

4. Chen J. Pathogenicity and transmissibility of 2019-nCoV-a quick overview and comparison with other emerging viruses. Microbes Infect. 2020;22:69-71.

https://doi.org/10.1016/j.micinf.2020.01.004

5. Ge Z-y, Yang L-m, Xia J-j, Fu X-h, Zhang Y-z. Possible aerosol transmission of COVID-19 and special precautions in dentistry $\mathrm{J}$ Zhejiang Univ Sci B. 2020;21:361-68.

https://doi.org/10.1631/jzus.B2010010

6. Bouguezzi A, Cherni I, Sioud S, Hentati H, Selmi J. COVID-19: Special precautions in dentistry. Open Access J Biomed Sci. 2020;2:28384.

https://doi.org/10.38125/OAJBS.000164

7. ADA recommending dentists postpone elective procedures. Available at: https://www.ada.org/ en/publications/ada-news/2020archive/march/ada-recommending-dentists-postponeelective-procedures. Accessed on March 18.

8. Cagetti MG, Cairoli JL, Senna A, Campus G. COVID-19 outbreak in North Italy: An overview on dentistry. A questionnaire survey. Int J Environ Res Public Health. 2020;17:3835.

https://doi.org/10.3390/ijerph17113835 
Bari YA/ Waqar SM/ Nasir S/ Zafar K/ Baig NN/ Shoro FN/ Abid K/

9. Khader Y, Al Nsour M, Al-Batayneh OB, Saadeh R, Bashier H, Alfaqih M, et al. Dentists' awareness, perception, and attitude regarding COVID-19 and infection control: cross-sectional study among Jordanian dentists. JMIR Public Health Surveill. 2020;6:e18798. https://doi.org/10.2196/18798

10. Stangvaltaite-Mouhat L, Uhlen M-M, Skudutyte-Rysstad R, Szyszko Hovden EA, Shabestari M, Ansteinsson VE. Dental Health Services Response to COVID-19 in Norway. Int J Environ Res Public Health. 2020;17:5843.

https://doi.org/10.3390/ijerph17165843

11. Samaranayake LP, Peiris M. Severe acute respiratory syndrome and dentistry: a retrospective view. J Am Dent Assoc. 2004;135:1292302.

https://doi.org/10.14219/jada.archive.2004.0405

12. Modi PD, Nair G, Uppe A, Modi J, Tuppekar B, Gharpure AS, et al. COVID-19 awareness among healthcare students and professionals in Mumbai metropolitan region: a questionnaire-based survey. Cureus. 2020;12:e7514.

https://doi.org/10.7759/cureus.7514

13. Gambhir RS, Dhaliwal JS, Aggarwal A, Anand S, Anand V, Bhangu AK. Covid-19: a survey on knowledge, awareness and hygiene practices
Infection control measures in Pakistani dental practices during COVID-19 outbreak

among dental health professionals in an Indian scenario. Rocz Panstw Zakl Hig. 2020;71:223-29.

https://doi.org/10.32394/rpzh.2020.0115

14. Seto W, Tsang D, Yung R, Ching T, Ng T, Ho M, et al. Effectiveness of precautions against droplets and contact in prevention of nosocomial transmission of severe acute respiratory syndrome (SARS). Lancet. 2003;361:1519-20.

https://doi.org/10.1016/S0140-6736(03)13168-6

15. Teleman MD, Boudville I, Heng B, Zhu D, Leo Y. Factors associated with transmission of severe acute respiratory syndrome among healthcare workers in Singapore. Epidemiol Infect. 2004;132:797-803. https://doi.org/10.1017/S0950268804002766

16. Wen Z, Yu L, Yang W, Hu L, Li N, Wang J, et al. Assessment the protection performance of different level personal respiratory protection masks against viral aerosol. Aerobiologia. 2013;29:365-72. https://doi.org/10.1007/s10453-012-9286-7

17. Umer F, Haji Z, Zafar K. Role of respirators in controlling the spread of Novel Coronavirus (COVID-19) among dental health care providers: a review. Int Endod J. 2020;53:1062-67.

https://doi.org/10.1111/iej.13313 